\title{
Effects of elite athletes' aim orientation on basic psychological needs and fear of failure
}

\author{
Şeker R. ${ }^{\mathrm{ABCDE}}$ \\ Department of Recreation, High School of Physical Education and Sports, Hatay Mustafa Kemal University, Hatay, \\ Turkey.
}

Authors' Contribution: A - Study design; B - Data collection; C - Statistical analysis; D - Manuscript Preparation; E - Funds Collection.

\begin{abstract}
Purpose: $\quad$ This research was carried out in order to analyze elite athletes' aim orientation, basic psychological needs and fear of failure in perspective of several variables, and to reveal the differences among these variables.

Material: $\quad$ Sample of the research consisted of elite athletes from different branches who had been in different regions of Turkey in 2016-2017. Number of elite athletes in this research was $(n=521)$ in total, 378 of whom were males and 173 of whom were females. These elite athletes had been chosen by random sampling. As data collection tools, Basic Psychological Needs Scale, which was adapted to Turkish by Kesici et al (2003), Fear of Failure Scale which was adapted to Turkish by Kahraman and Sungur (2016), Scale of Task and Ego Orientation in Sports that was adapted to Turkish by Toros (2004) were used in the study.

Results: It was concluded that females had lower fear of "unclear future" and "experiencing shame and embarrassment" than males. It was revealed that as the age of the participants went up, their needs for relationship, fear of unclear future, fear of experiencing shame and embarrassment, and task orientation increase. It was found out that participants who had direct branches had higher "need for relationship" and "fear of unclear future" in comparison with the ones who had indirect branches.

Conclusions: According to the results of the study, it was found that there was meaningful difference in sub-dimensional fear of failure in terms of gender variable, in sub-dimensional fear of failure, in basic psychological needs and in aim orientation with regards to age variable, in sub-dimensional basic psychological needs and in fear of failure in terms of branch variation (direct - indirect) variable.

Keywords: aim, ego, fear of failure, orientation, psychological needs.
\end{abstract}

\section{Introduction}

Being successful on life purposes, achieving goals in life help humans get satisfied in their lives $[1,2]$. Therefore, life satisfaction eases participating more in activities, and desire of being satisfied and happy encourages doing sports activities. As with daily life, succeeding in sports makes people happy; therefore, it is important how success is labeled by individuals. For instance, while success means getting medals for some athletes; it may mean self-development for the others. Aim orientation has an important place especially in sports environment. In relation with motivation, aim orientation appears in two forms which are related with task and ego. These two concepts compose two extents which are separated from each other, yet connected with each other as well. In task-related aim orientation, an athlete compares his/ her own past performance standards and level of skill with the present. In this way, the athlete gets satisfied with himself/herself by developing his/her athletic skills and knowledge. As the issue is to get a positive self-image by carrying his/her level of skill to the next level, the athlete tries to do his/her best not only during a competition, but also during training. In ego-related aim orientation, the athlete uses his/her teammates and rivals as a standard for his/her own skills. Therefore, the athlete becomes satisfied with himself/herself as long as he/she dominates the others. Supremacy, inferiority feelings, famousness and standing out are the main stimulations in

(c) Şeker R., 2019

doi:10.15561/18189172.2019.0308 this orientation. Ego-related aim orientation is observed generally in elite athletes who have completed skill development and sustain task-related aim orientation at a certain level. Besides, there are also situations in which the two orientations in athletes are in balance, or aren't considered separately [3-5].

It is an approved fact that in addition to physical fitness, psychological fitness of athletes is also substantial in order to get high performance in sports settings [6]. Individuals' self-feeling of adequacy about their actions and doing their tasks successfully allow them to have high self-confidence and improve their needs of adequacy [7].

It is expected that providing psychological needs necessary for the individuals will increase the confidence of them and increase the sense of self-assurance in activities or events in a positive way [8]. However, if the individuals cannot meet their psychological needs, it is expected that fear of failure inevitably haunts them. The more the individual feeds his/her own orientation and psychological needs, the easier his/her orientation to succeed is. For example, an athlete's desire for competing in the Olympics is an inherent feeling. However, in order to actualize this feeling, he/she needs to fill some specific criteria in by reaching serious successes in competitions before the Olympics. For this, primarily, determining his/ her goals, then finding a decent trainer and having a strong psychology are the most important criteria for the athlete to find himself/herself and to focus on success. Though, deficient guidance or a non-satisfied psychology may cause ending the athlete's adventure before it is started 
[9].

Concisely, this study, which was intended to be directed towards researching of the effect of elite athlete's aim orientation on basic psychological needs and fear of failure, was tried to be revealed in a descriptive way. It was seen that motivation level of athletes that were created through their lives to orient to particular aims changed for various reasons. It was seen that among the main problems experienced during the motivation in the way of the aim, were the reasons arose from not meeting the psychological needs of the individual and the fear of failing. Elimination of fear of failure and psychological needs not only will increase the satisfaction of the athletes and allow to motivate mentally and affectively in sportive terms, but also offer important opportunities to get the athlete to the aim he/she determined particularly to an aim.

\section{Materials and Methods}

\section{Research model}

The research was in relational screening model and presented a descriptive quality. Screening model tries to describe a situation exists in the past or present as it is [10]. Investigating effects of elite athletes' aim orientation on basic psychological needs and fear of failure in perspective of several variables was the frame of the research.

\section{Subjects}

Research group consisted of elite athletes who had participated actively in the 2016-2017 competition season in different regions of Turkey, and they were chosen with random sampling. Number of the athletes was 521 (Wrestling (53), Barbell (46), Boxing (40), Taekwondo (39), Karate (37), Judo (34), Athletics (47), Muay-Thai (33), Swimming (27), Kick-box (38), Arm Wrestling (27), Wushu (39), Gymnastics (25), Fencing (20), Orienteering (16)). The athletes in the sampling were chosen from the mass of athletes who have continued their sports lives actively.

\section{Data Collection}

Basic psychological needs scale. Basic Psychological Needs Scale was devised by Deci and Ryan, and was adapted to Turkish by Kesici et al. [11-12]. This scale was adapted to Turkish to detect an individual's basic psychological needs and there were 21 statements in the original form of the scale.

How individuals' needs towards various fields were presented and how often individuals wished this situation, were asked in the scale. The scale originally used a septet gradation type but a quintet gradation type was preferred while adapting to Turkish. Scale items that included positive statements were graded as such: very accurate: 5 , accurate: 4 , less accurate: 3 , not accurate: 2 , not accurate at all: 1 . The scale consisted of three sub-dimensions. By counting the score a person took from the items in a subdimension, scale scores in three sub-dimensions for each individual were obtained. These three sub-dimensions respectively were: need for autonomy (1st, 4 th, 17 th, 20th, 8th, 11th, 14th items), need for competence (3rd, 5th, 10th, 19th, 13th, 15th items), need for relationship (2nd, 12th, 16th, 18th, 21st, 6th, 7th, 9th items).

Theoretically, as grading each item was set among 1 and 5, total score of the scale in terms of autonomy subdimension was 35 at most and 7 at least. As the score went up, individual felt more that his/her psychological needs were met, and when it went down he/she felt psychological needs. Total score in terms of competence needs sub-dimension was 30 at most and 6 at least. Total grade in terms of relationship needs sub-dimension was 40 at most and 8 at least. For instance, an individual's having a high grade in competence sub-dimension meant one felt himself/herself more competent. Reliability values regarding the sub-dimensions respectively were $0.82,0.86$ and 0.84 . As a result of the analysis that was done on the data obtained from this study, reliability values regarding the scale's sub-dimensions respectively were: $0.79,0.85$ and 0.83 .

Performance Failure Appraisal Inventory. It was developed by Conroy, updated by Conroy et al, and adapted to Turkish by Kahraman and Sungur [13, 14, 15]. It consisted of 25 items. It had a five point Likert form. Since it had too many reverse-grading items and it was too long, Conroy et al. (2002) revised the scale and updated it by removing some items [14]. The scale included 25 items and 5 dimensions in this current form. The dimensions were: Fear of Lowering Someone's Self-Judgment Value (1st, 4th, 7th, 16th items); Fear of Unclear Future (2nd, 5th, 8th, 12th); Fear of Disappointing Important People (3rd, 6th, 9th, 14th, 19th); Fear of Experiencing Shame and Embarrassment (10th, 15th, 18th, 20th, 22nd, 2nd); Fear of Wasting Attention of Important People (11th, 17th, 13th, 21st, 23rd). Validity study of the updated scale was held with 438 university students. Cronbach alpha values of the dimensions were found as; 0.80 for fear of experiencing shame and embarrassment, 0.74 for fear of lowering someone's self-judgment value, 0.80 for fear of unclear future, 0.78 for fear of wasting attention of important people and 0.78 for fear of disappointing important people. According to the DFA results, the model had decent adaptation index. Consequently, the scale was valid and reliable for measuring fear of failure. In result of the analysis that was done on the data obtained from this study, Cronbach alpha reliability values regarding the scale's sub-dimensions respectively were: $0.81,0.78$, $0.79,0.81$ and 0.80 .

Task and Ego Orientation in Sport Questionnaire. Being devised by Duda and adapted to Turkish by Toros, Task and Ego Orientation in Sport Questionnaire (TEOSQ) based on achievement goal theory $[4,16]$. The questionnaire consisted of five point Likert type which was expressed in a format of "strongly disagree, disagree, neutral, agree, strongly agree". The questionnaire included 13 items regarding five evaluation stages of attitudes and it involved two sub-scales. The first one imported Task Orientation (2nd, 5th, 7th, 8th, 10th, 12th, 13th items) and the second one imported Ego Orientation (1st, 3rd, 4th, 6th, 9th, 11th) and they comprised of 13 items in total. Cronbach alpha values of the sub-dimensions were 
calculated as; 0.65 for Task Orientation and 0.72 for Ego Orientation. In result of the analysis that was done on the data acquired from this study, reliability values regarding the scale's sub-dimensions respectively were: 0.76 and 0.81 .

\section{Statistical Analysis}

The data of this study were collected by distributing the scales to pre-service teachers in preschool teacher education. The data obtained from the study was analyzed using SPSS 20.0. Kolmogorov-Smirnov test was applied in order to examine whether the data showed normal distribution. Since it was detected that the data was not distributed normally, non-parametric test was employed. Depending on sub-problems, percentage, frequency, standard deviation, arithmetic mean, Mann-Whitney, Kruskal-Wallis test and correlation analysis were used in the data analysis. In significance test, the level of significance was regarded as 0.05 .

\section{Results}

This section included statistical evaluation of the information obtained from the responses given by the athletes participating in the study to the form of Basic Psychological Needs, Performance Failure Appraisal Inventory and Task and Ego Orientation in Sport Questionnaire.

According to the Table 1, in result of Mann-Whitney $\mathrm{U}$ test, only significant difference was found in terms of gender variable is in "Fear of Unclear Future" and
"Fear of Experiencing Shame and Embarrassment" sub-dimensions under the performance failure appraisal questionnaire, which was in favor of females $(* p<, 05$; $* * \mathrm{p}<, 01)$. According to this result, it can be said that females' fear of "unclear future" and "experiencing shame and embarrassment" was lower than males'.

When the results of Kruskal-Wallis test in Table 2 were examined, a significant difference was found in "Need for Relationship" sub-dimension under the basic psychological needs scale, in "Fear of Unclear Future" and "Fear of Experiencing Shame and Embarrassment" sub-dimension under the performance failure appraisal scale and in "Task Orientation" sub-dimension under the task and ego orientation in sport questionnaire, in terms of age variable $(* \mathrm{p}<, 01 ; * \mathrm{*}<, 05)$. Mann-Whitney $\mathrm{U}$ test was used in order to detect among which age groups this difference occurred. It was found out that as the age of the participants increased, their needs for relationship, fear of unclear future, fear of experiencing shame and embarrassment, and task orientation also went up.

According to the Table 3, result of Mann-Whitney $\mathrm{U}$ test, significant difference found in terms of branch variable was in "Need for Relationship" sub-dimension under the basic psychological needs scale and in "Fear of Unclear Future" sub-dimension under the performance failure appraisal questionnaire, which was in favor of the participants whose branches were direct $(* \mathrm{p}<, 01 ; * * \mathrm{p}<$ , 05). In guidance of this result, it can be said that "Need for Relationship" and "Fear of Unclear Future" levels of

Table 1. Evaluation of the grades of the participants' basic psychological needs, performance failure appraisal and task and ego orientation in sport according to gender variable

\begin{tabular}{|c|c|c|c|c|c|c|c|}
\hline Dimensions & Gender & $\mathbf{n}$ & $\bar{x}$ & $\begin{array}{l}\text { Mean } \\
\text { Rank }\end{array}$ & $\begin{array}{l}\text { Mean } \\
\text { Total }\end{array}$ & $\mathbf{U}$ & $\mathbf{p}$ \\
\hline \multirow{2}{*}{ Need for Autonomy } & Male & 378 & 20.12 & 284.13 & 107400.50 & \multirow{2}{*}{29624.5} & \multirow{2}{*}{.075} \\
\hline & Female & 173 & 19.65 & 258.24 & 44675.50 & & \\
\hline \multirow{2}{*}{ Need for Competence } & Male & 378 & 20.91 & 285.98 & 108100.50 & \multirow{2}{*}{28924.5} & \multirow{2}{*}{.059} \\
\hline & Female & 173 & 20.26 & 254.19 & 43975.50 & & \\
\hline \multirow{2}{*}{ Need for Relationship } & Male & 378 & 28.62 & 284.67 & 107603.50 & \multirow{2}{*}{29421.5} & \multirow{2}{*}{.058} \\
\hline & Female & 173 & 27.82 & 257.07 & 44472.50 & & \\
\hline \multirow{2}{*}{$\begin{array}{l}\text { Fear of Lowering someone's Self- } \\
\text { Judgment Value }\end{array}$} & Male & 378 & 7.51 & 281.66 & 106468.00 & \multirow{2}{*}{30557.0} & \multirow{2}{*}{.212} \\
\hline & Female & 173 & 7.36 & 263.63 & 45608.00 & & \\
\hline \multirow{2}{*}{ Fear of Unclear Future } & Male & 378 & 10.47 & 296.91 & 112231.50 & \multirow{2}{*}{24793.5} & \multirow{2}{*}{$.000 * *$} \\
\hline & Female & 173 & 9.45 & 230.32 & 39844.50 & & \\
\hline \multirow{2}{*}{$\begin{array}{l}\text { Fear of Disappointing Important } \\
\text { People }\end{array}$} & Male & 378 & 14.13 & 283.23 & 107059.50 & \multirow{2}{*}{29965.5} & \multirow{2}{*}{.113} \\
\hline & Female & 173 & 13.72 & 260.21 & 45016.50 & & \\
\hline \multirow{2}{*}{$\begin{array}{l}\text { Fear of Experiencing Shame and } \\
\text { Embarrassment }\end{array}$} & Male & 378 & 18.44 & 287.24 & 108577.50 & \multirow{2}{*}{28447.5} & \multirow{2}{*}{$.014 *$} \\
\hline & Female & 173 & 17.45 & 251.44 & 43498.50 & & \\
\hline \multirow{2}{*}{$\begin{array}{l}\text { Fear of wasting Attention of } \\
\text { Important People }\end{array}$} & Male & 378 & 10.69 & 283.30 & 107088.00 & \multirow{2}{*}{29937.0} & \multirow{2}{*}{.110} \\
\hline & Female & 173 & 10.16 & 260.05 & 44988.00 & & \\
\hline \multirow{2}{*}{ Task Orientation } & Male & 378 & 19.20 & 273.51 & 103387.00 & \multirow{2}{*}{31756.0} & \multirow{2}{*}{.586} \\
\hline & Female & 173 & 19.62 & 281.44 & 48689.00 & & \\
\hline \multirow{2}{*}{ Ego Orientation } & Male & 378 & 22.24 & 274.68 & 103830.50 & \multirow{2}{*}{32199.5} & \multirow{2}{*}{.774} \\
\hline & Female & 173 & 22,41 & 278,88 & 48245,50 & & \\
\hline
\end{tabular}

Note: $* ; p<.05, * * ; p<.01$ 
Table 2. Evaluation of the grades of the participants' basic psychological needs, performance failure appraisal and task and ego orientation in sport according to age variable

\begin{tabular}{|c|c|c|c|c|c|c|c|c|}
\hline Variables & Age & $\mathbf{N}$ & $\dot{x}$ & $\begin{array}{l}\text { Mean } \\
\text { Rank }\end{array}$ & Sd & $\chi^{2}$ & $\mathbf{P}$ & $\begin{array}{l}\text { Significant } \\
\text { Difference }\end{array}$ \\
\hline \multirow{3}{*}{ Need for Autonomy } & $10-18$ age & 130 & 20.25 & 288.47 & & & & \multirow{9}{*}{$\begin{array}{l}1-3 \\
2-3\end{array}$} \\
\hline & $19-22$ age & 252 & 19.80 & 269.86 & 2 & 1.181 & .554 & \\
\hline & 23 and older & 169 & 20.02 & 275.57 & & & & \\
\hline \multirow{3}{*}{ Need for Competence } & $10-18$ age & 130 & 20.69 & 281.72 & & & & \\
\hline & $19-22$ age & 252 & 20.59 & 269.50 & 2 & .779 & .677 & \\
\hline & 23 and older & 169 & 20.89 & 281.29 & & & & \\
\hline \multirow{3}{*}{ Need for Relationship } & 10-18 age & 130 & 27.68 & 252.25 & \multirow{3}{*}{2} & \multirow{3}{*}{7.559} & \multirow{3}{*}{$.023^{*}$} & \\
\hline & 19-22 age & 252 & 28.22 & 271.05 & & & & \\
\hline & 23 and older & 169 & 29.13 & 301.65 & & & & \\
\hline \multirow{3}{*}{$\begin{array}{l}\text { Fear of Lowering } \\
\text { someone's Self- } \\
\text { Judgment Value }\end{array}$} & $10-18$ age & 130 & 7.46 & 277.12 & \multirow{3}{*}{2} & \multirow{3}{*}{1.644} & \multirow{3}{*}{.440} & \\
\hline & $19-22$ age & 252 & 7.59 & 283.69 & & & & \\
\hline & 23 and older & 169 & 7.27 & 263.68 & & & & \\
\hline \multirow{3}{*}{ Fear of Unclear Future } & 10-18 age & 130 & 9.07 & 203.13 & \multirow{3}{*}{2} & \multirow{3}{*}{39.688} & \multirow{3}{*}{$.000 * *$} & $1-2$ \\
\hline & $19-22$ age & 252 & 10.27 & 286.63 & & & & $1-3$ \\
\hline & 23 and older & 169 & 10.80 & 316.20 & & & & $2-3$ \\
\hline \multirow{3}{*}{$\begin{array}{l}\text { Fear of Disappointing } \\
\text { Important People }\end{array}$} & 10-18 age & 130 & 13.66 & 255.91 & \multirow{3}{*}{2} & \multirow{3}{*}{5.256} & \multirow{3}{*}{.072} & \\
\hline & 19-22 age & 252 & 13.92 & 272.19 & & & & \\
\hline & 23 and older & 169 & 14.39 & 297.14 & & & & \\
\hline \multirow{3}{*}{$\begin{array}{l}\text { Fear of Experiencing } \\
\text { Shame and } \\
\text { Embarrassment }\end{array}$} & 10-18 age & 130 & 17.43 & 249.05 & \multirow{3}{*}{2} & \multirow{3}{*}{6.277} & \multirow{3}{*}{$.043^{*}$} & \multirow{3}{*}{$1-3$} \\
\hline & $19-22$ age & 252 & 18.18 & 276.89 & & & & \\
\hline & 23 and older & 169 & 18.60 & 295.40 & & & & \\
\hline Fear of Wasting & 10-18 age & 130 & 9.93 & 247.24 & \multirow{3}{*}{2} & \multirow{3}{*}{5.608} & \multirow{3}{*}{.061} & \\
\hline Attention of Important & 19-22 age & 252 & 10.68 & 284.87 & & & & \\
\hline \multirow[t]{2}{*}{ People } & 23 and older & 169 & 10.73 & 284.90 & & & & \\
\hline & $10-18$ age & 130 & 18.66 & 249.14 & & & & \\
\hline \multirow[t]{2}{*}{ Task Orientation } & 19-22 age & 252 & 19.28 & 269.30 & 2 & 10.492 & $.005^{* *}$ & $\begin{array}{l}1-3 \\
2-3\end{array}$ \\
\hline & 23 and older & 169 & 19.93 & 306.64 & & & & \\
\hline & 10-18 age & 130 & 21.46 & 251.98 & & & & \\
\hline Ego Orientation & 19-22 age & 252 & 22.39 & 276.37 & 2 & 5.129 & .077 & \\
\hline & 23 and older & 169 & 22.78 & 293.93 & & & & \\
\hline
\end{tabular}

Note: ${ }^{*} p<.05 ; * * p<.01 ; 1: 10-18$ age.2: 19-22 age.3: 23 and older

the participants whose branches were direct were higher than of the ones whose branches were indirect.

\section{Discussion}

In this study, effects of aim orientation on elite athletes' basic psychological needs and fear of failure were investigated, and the statistical results of the data obtained from the demographical values regarding the athletes were intended to be discussed in this section. The demographical values were assessed according to the subdimensions of the scales and a discussion and conclusion section was created with the results revealed.

It was concluded that females' fear of "unclear future" and "experiencing shame and embarrassment" was lower than males'. It was also observed that females' worry about unclear future and level of experiencing shame and embarrassment which were sub-dimensions of the fear of failure scale was seriously lower than males'. It can be said that sub-dimensions of the fear of failure, such as achievement goals, shame and embarrassment and unclear future, have an indirect effect on the fear of failure, task selection, displaying task and performance of gender studies. In a sense, this fear has a domino effect. It directly affects the adaption of achievement goals and the achievement goal affects achievement behavior directly [17-19]. In a study, Engür showed that although there was no significant relation between Experiencing Shame and Embarrassment sub-dimension, males had higher mean points [20]. Elison et al. stated that males showed avoiding behavior mostly in embarrassment situations but females generally internalized embarrassment [21]. In their study towards secondary school students, Kahraman and Sungur found significant difference between males and females in terms of shame and embarrassment subdimensions under the fear of failure [15]. When Engür's study was studied, it was detected that although there was 
Table 3. Evaluation of the grades of the participants' basic psychological needs, performance failure appraisal and task and ego orientation in sport according to branch variable

\begin{tabular}{|c|c|c|c|c|c|c|c|}
\hline Dimensions & Branch & $\mathbf{N}$ & $\dot{x}$ & $\begin{array}{l}\text { Mean } \\
\text { Rank }\end{array}$ & Mean Total & $\mathbf{U}$ & $\mathbf{p}$ \\
\hline \multirow{2}{*}{ Need for Autonomy } & Direct & 344 & 20.18 & 283.51 & 97526.50 & \multirow{2}{*}{33021.50} & \multirow{2}{*}{.152} \\
\hline & Indirect & 207 & 19.65 & 263.52 & 54549.50 & & \\
\hline \multirow{2}{*}{ Need for Competence } & Direct & 344 & 20.92 & 283.74 & 97605.50 & \multirow{2}{*}{32942.50} & \multirow{2}{*}{.140} \\
\hline & Indirect & 207 & 20.36 & 263.14 & 54470.50 & & \\
\hline \multirow{2}{*}{ Need for Relationship } & Direct & 344 & 28.77 & 288.01 & 99076.00 & \multirow{2}{*}{31472.00} & \multirow{2}{*}{$.022 *$} \\
\hline & Indirect & 207 & 27.71 & 256.04 & 53000.00 & & \\
\hline \multirow{2}{*}{$\begin{array}{l}\text { Fear of Lowering } \\
\text { someone's Self-Judgment } \\
\text { Value }\end{array}$} & Direct & 344 & 7.50 & 278.05 & 95647.50 & \multirow[b]{2}{*}{34900.50} & \multirow[b]{2}{*}{.694} \\
\hline & Indirect & 207 & 7.41 & 272.60 & 56428.50 & & \\
\hline \multirow{2}{*}{ Fear of Unclear Future } & Direct & 344 & 10.38 & 291.53 & 100285.00 & \multirow{2}{*}{30263.00} & \multirow{2}{*}{$.003 * *$} \\
\hline & Indirect & 207 & 9.78 & 250.20 & 51791.00 & & \\
\hline \multirow{2}{*}{$\begin{array}{l}\text { Fear of Disappointing } \\
\text { Important People }\end{array}$} & Direct & 344 & 13.98 & 274.63 & 94473.50 & \multirow{2}{*}{35133.50} & \multirow{2}{*}{.794} \\
\hline & Indirect & 207 & 14.06 & 278.27 & 57602.50 & & \\
\hline \multirow{2}{*}{$\begin{array}{l}\text { Fear of Experiencing } \\
\text { Shame and } \\
\text { Embarrassment }\end{array}$} & Direct & 344 & 18.10 & 274.61 & 94466.50 & \multirow[b]{2}{*}{35126.50} & \multirow[b]{2}{*}{.791} \\
\hline & Indirect & 207 & 18.20 & 278.31 & 57609.50 & & \\
\hline \multirow{2}{*}{$\begin{array}{l}\text { Fear of Wasting Attention } \\
\text { of Important People }\end{array}$} & Direct & 344 & 10.34 & 266.89 & 91809.50 & \multirow{2}{*}{32469.50} & \multirow{2}{*}{.082} \\
\hline & Indirect & 207 & 10.84 & 291.14 & 60266.50 & & \\
\hline \multirow{2}{*}{ Task Orientation } & Direct & 344 & 19.62 & 283.99 & 97691.50 & \multirow{2}{*}{32856.50} & \multirow{2}{*}{.127} \\
\hline & Indirect & 207 & 18.88 & 262.73 & 54384.50 & & \\
\hline \multirow{2}{*}{ Ego Orientation } & Direct & 344 & 22.53 & 283.44 & 97502.50 & \multirow{2}{*}{33045.50} & \multirow{2}{*}{.157} \\
\hline & Indirect & 207 & 21.91 & 263.64 & 54573.50 & & \\
\hline
\end{tabular}

Note: ${ }^{*} p<.05 ; * p<.01$

no significant difference between genders in terms of Fear of Unclear Future, mean scores of males were higher than of females [20].

It was found that as the age of participants went up, their fear of unclear future, of experiencing shame and embarrassment, and task orientation also increased. When we looked at these results, we saw that it was also the same for gender varieties. According to the results, age variable of elite athletes was tried to be discussed primarily in terms of relationship sub-dimension under basic psychological needs, secondarily in terms of fear of unclear future, fear of experiencing shame and embarrassment and task orientation sub-dimensions under fear of failure. It was seen that as age of elite athletes increased, their needs for relationship also increased. In his study towards wrestlers, Bayraktar concluded that as the athletes' age increased, their needs for relationship increased as well [22]. In his study, Atalay found that need for relationship for 18-27 age groups was dominant [23]. In their study towards sports sciences students, Sar1 et al. found that age variable was not a significant difference in terms of need for relationship [24]. Recently in a study of Kim published in Emotion by APA Publishing, it was detected that people who struggled with the potential uncertainness of future and its lexical blur (or people felt he/she had to overcome) and saw this uncertainness of future as a threat had an extremely big stratum area [25].

This brain area called stratum was known for its relation with general anxiety and anxiety disorder according to the previous studies and data. In the study published by American Psychological Association, Kim revealed that there was a connection between individual's overcoming of uncertainness of future / not seeing this as a problem and the intensity of gray matter in a certain area of the brain [25]. Fear of failure is a part of the domination struggle on our important issues, and it is inevitable and innate [26]. Weiner stated that stability increased the priority of future performance and instability increased uncertainness perception of future performance [27]. Weiner et al. interpreted individuals' success and failure in four categories which were skill, difficulty, effort and luck [28]. He expressed these for reasonable statements in three reasonable aspects which were focus of audit, stability and inspect ability. According to Wiener, these aspects were related to emotions such as anger, self-reproach, despair, pity, embarrassment and pride. Since Freud stated that main reason of fear of shame and embarrassment was worry, we might think fear of shame and embarrassment athletes had was resulted from worry [29]. Treasure, Carpenter and Power found that age variable had an effect on task orientation of football players [30]. In a study held with the students of Kocaeli University School of Physical 
Education and Sports regarding athletes' task orientation, no significant difference between task and aim orientation and age variable was found. It was observed that as age increased, task orientation pointed increase [31]. In his study of "Relation Between Task Orientation on Amateur and Professional Football Players and Perceived Motivational Atmosphere", Ungur suggested that there was no relation between age and task orientation [32].

It was determined that level of "need for relationship" and "fear of unclear future" of athletes whose branches were direct was higher than the ones whose branches were indirect. When we studied the findings, it was seen that sports which had direct branches had a higher level of need for relationship under basic psychological needs and fear of unclear future sub-dimension under fear of failure. When we analyzed Ünlü towards pre-service teachers of physical education and sports, it was found out that there was a significant difference in basic psychological needs in terms of branch variable. It was also found that athletes with team sports had higher need for relationship in comparison with the ones doing individual sports [33]. Bilge stated that there was no significant difference between national athletes and non-athletes in terms of basic psychological needs [34]. There was no significant difference between team sports and individual ones in terms of psychological needs. It was seen that our study had findings in reverse.

\section{Conclusion}

It was concluded that females had lower fear of "unclear future" and "experiencing shame and embarrassment" than males.

It was revealed that as the age of the participants went up, their needs for relationship, fear of unclear future, fear of experiencing shame and embarrassment, and task orientation increase.

It was found out that participants who had direct branches had higher "need for relationship" and "fear of unclear future" in comparison with the ones who had indirect branches.

\section{Highlights}

Females had lower fear of "unclear future" and "experiencing shame and embarrassment" than males.

The age of the participants went up, their needs for relationship, fear of unclear future, fear of experiencing shame and embarrassment, and task orientation increase.

Direct branches had higher "need for relationship" and "fear of unclear future" in comparison with the ones who had indirect branches.

\section{Acknowledgment}

We gratefully acknowledge the help of all the participant who took part in the study.

\section{Funding}

The authors received no financial support for the research, authorship, and/or publication of this article.

\section{Conflict of interests}

The authors state that there is no conflict of interest.

\section{References}

1. Diener E. Subjective well-being. Psychological Bulletin, 1984; 95(3): 542-75. https://doi.org/10.1037/0033-2909.95.3.542

2. Yetim Ü. Toplumdan Bireye Mutluluk Resimleri [Happiness From Society]. Ankara: Bağlam Yayınları; 2000. (In Turkish)

3. Bruin AP, De Bakker FC, Oudejans RRD. Achievement goal theory and disordered eating: Relationships between female gymnasts' goal orientations, perceived motivational climate and disordered eating correlates. Psychology of Sport and Exercise, 2009;10:72- 9. https://doi.org/10.1016/j.psychsport.2008.07.002

4. Duda JL. Relationship between task and ego orientation and the perceived purpose of sport among high school athletes. Journal of Sport and Exercise Psychology, 1989;11, 318- 35. https://doi.org/10.1123/jsep.11.3.318

5. FigueiredoAJ, Goncalves CE, Silva MJCE, Malina RM. Youth soccer players, 11-14 years: Maturity, size, function, skill and goal orientation. Annals of Human Biology, 2009;36(1):60-73. https://doi.org/10.1080/03014460802570584

6. Jackson S, Thomas P, Marsh H, Smethurst C. Relationships between flow, self-concept psychological skills, and performance. Journal of Applied Sport, 2001;13(2): 129- 53. https://doi.org/10.1080/104132001753149865

7. Ryan RM, Sheldon KM, Kasser T, Deci EL. All goals are not created equal: An organismic perspective on the nature of goals and their regulation. Psychology, 1996;13:129-53.

8. Gülle M. Investigation of physical education and sports high school students' critical thinking and empathy level.
(Doctoral dissertation). Institute of Education Sciences, Sakarya University; 2015.

9. Seker R. Effects of elite sportsmen's goal orientation on basic psychological needs and fear of failure. Çorum: Institute of Health Sciences, Hitit University; 2017.

10.Karasar N. Bilimsel Araştırma Yöntemi [Scientific Research Method]. Ankara: Nobel Yayıncılık; 2012. (In Turkish)

11.Deci EL, Ryan RM. The "What" and "Why" of goal pursuits: Human needs and the self-determination of behavior. Psychological Inquiry, 2000;11(4):227- 68. https://doi.org/10.1207/S15327965PLI1104_01

12.Kesici Ş, Üre Ö, Bozgeyikli H, Sünbül AM. Temel psikolojik ihtiyaçlar ölçeğinin geçerlik ve güvenirliği [Validity and reliability of the basic psychological needs scale]. VII. National PDR Proceding Book, Inonu University, Malatya; 2003. (In Turkish)

13.Conroy D E. Fear of failure: An exemplar for social development research in sport. Quest, 2001;53(2):165- 83. https://doi.org/10.1080/00336297.2001.10491736

14.Conroy DE, Willow JP, Metzler JN. Multidimensional measurement of fear of failure: The performance failure appraisal inventory. Journal of Applied Sport Psychology, 2002;14:76- 90. https://doi.org/10.1080/10413200252907752

15.Kahraman N, Sungur S. Adaptation of the performance failure appraisal inventory (PFAI) into Turkish. Journal of Kirsehir Education Faculty, 2016;17(3):223-39.

16.Toros T. Goal orienration, motivational cumate and life satisfaction among elite and non-elite male basketball players 
in Turkey. Hacettepe Üniversitesi Spor Bilimleri Dergisi, 2001;13(3):24-36.

17.Conroy DE, Elliot AJ. Fear of failure and achievement goals in sport: Addressing the issue of the chicken and the egg. Anxiety, Stress \& Coping: An International Journal, 2004;17(3):271- 285. https://doi.org/10.1080/1061580042000191642

18.Elliot AJ, Sheldon KM, Church MA. Avoidance personal goals and subjective well-being. Personality and Social Psychology Bulletin, 1997;23(9):915- 27. https://doi.org/10.1177/0146167297239001

19. Elliot AJ, Shell MM, Henry KB, Maier MA. Achievement goals, performance contingencies, and performance attainment: An experimental test. Journal of Educational Psychology, 2005;97(4): 630. https://doi.org/10.1037/0022-0663.97.4.630

20.Engür M. Performans başarısızlĭ̆ değerlendirme envanteri ve kendinle konuşma anketi 'nin Türk Sporcu Popülasyonu'na uyarlanmast ve uygulanmasi [The Performance failure appraisal inventory and self-talk questionnaires adapted into Turkish for athletes.]. (Doctoral dissertation), İzmir: Institute of Health Sciences, Ege University; 2011. (In Turkish)

21.Elison J, Pulos S, Lennon R. Shame-focused coping: An empirical study of the compass of shame. Social Behavior and Personality: An International Journal, 2006;34(2):161- 68. https://doi.org/10.2224/sbp.2006.34.2.161

22.Bayraktar G. The relevance of wrestlers' assertiveness with their individual success. Selçuk University Journal of Physical Education and Sport Science, 2007;12(1):6-11. (In Turkish)

23.Atalay F. Yuva ögretmenlerinin psikolojik ihtiyaç örüntüleri [The psychological need patterns of pre-school teachers] (Master's thesis). Ankara: Institute of Social Sciences, Gazi University; 1994. (In Turkish)

24.Sarı İ, Yenigün Ö, Altıncı EE, Öztürk A. Effect of satisfaction of the basic psychological needs on general self-efficacy and trait anxiety (Example of Sakarya University department of sport management). Spormetre, 2011;9(4):149-56.
25.Kim MJ, Shin J, Taylor J, Mattek A, Samantha C, Whalen P. Intolerance of uncertainty predicts increased striatal volume. Emotion, 2017;17(6):895- 99. https://doi.org/10.1037/emo0000331

26. Vealey RS. Fear of failure in the context of competitive sport: a commentary. International Journal of Sports Science \& Coaching, 2008;3(2):179- 83. https://doi.org/10.1260/174795408785100752

27. Weiner B. A theory of motivation for some classroom experiences.JournalofEducationalPsychology, 1979;71:3-25. https://doi.org/10.1037/0022-0663.71.1.3

28. Weiner B, Frieze I, Kukla A, Reed L, Rest S, Rosenbaum RM. Perceiving the causes of success and failure. In: Jones EE, Kanouse DE, Kelley HH, Nisbett RR, Valling S, Weiner B. (Eds.), Attribution: Perceiving the Causes of Behavior. Morristown, NJ: General Learning Pres; 1972.

29.Freud S. The Problem of Anxiety. New York: Norton; 1936.

30. Treasure DC, Paul J, Carpenter PJ, Power KTD. Relationship between achievement goal orientations and the perceived purposes of playing rugby union for professional and amateur players. Journal of Sports Sciences, 2000;5(18):571- 77. https://doi.org/10.1080/02640410050082288

31.Kaygusuz Ş, Körmükçü Y, Adalı H. Examination of life satisfaction with ego and duty tendency in sports by variables for students of school of physical education and sports. International Journal of Science Culture and Sport, 2016;4(Supp..3):853- 53. https://doi.org/10.14486/IntJSCS635

32.Üngür G. Amatör ve profesyonel futbolcularda hedef yönelimi ve algılanan motivasyonel iklim arasindaki ilişki [The relationship between goal orientation and percerved motivational climate in amateur and professional footballers] (Master's thesis). İzmir: Institute of Health Sciences, Ege University; 2019.

33.Ünlü H. Basic psychological needs of preservice physical education teacher. Sport Sciences, 2009;4(3):210-17.

34.Bilge F. Sporcuların psikolojik ihtiyaçları [The psychological needs of sportsmen]. Spor Bilimleri Dergisi, 1992;3(2):1017. (In Turkish)

\section{Information about the author:}

Şeker R.; http://orcid.org/0000-0002-8624-7113; r.seker@hotmail.com; Department of Recreation, High School of Physical Education and Sports, Hatay Mustafa Kemal University; Tayfur Sokmen Campus, 31040, Antakya, Hatay, Turkey.

Cite this article as:

Şeker R. Effects of elite athletes' aim orientation on basic psychological needs and fear of failure. Pedagogics, psychology, medical-biological problems of physical training and sports, 2019;23(3):155-161. https://doi.org/10.15561/18189172.2019.0308

This is an Open Access article distributed under the terms of the Creative Commons Attribution License, which permits unrestricted use, distribution, and reproduction in any medium, provided the original work is properly cited (http://creativecommons.org/licenses/by/4.0/deed.en).

Received: 02.04.2019

Accepted: 29.04.2019; Published: 29.06.2019 